\title{
Absence of Mutations in PAX6 Gene in Three Cases of Morning Glory Syndrome Associated with Isolated Growth Hormone Deficiency
}

\begin{abstract}
Morning glory syndrome (MGS) is a congenital optic disc dysplasia often associated with craniofacial anomalies, especially basal encephalocele and hypopituitarism. Clinical signs are varied and often occult. The PAX6 gene is involved in ocular morphogenesis and is expressed in numerous ocular tissues during development especially in the developing central nervous system. The aim of the present study is to evaluate PAX6 in MGS associated with isolated growth hormone deficiency. Three pre-pubertal males (A, B and C) with MGS and short stature due to growth hormone deficiency, treated with recombinant human growth hormone with limited response, were reported. Two of them had basal encephalocele. Coding and non-coding sequences corresponding of PAX6 different transcripts were analyzed by direct sequencing. Nucleotide variations causing putative aminoacid change were not observed. Patient $A$ presented the new IVS2+9G>A transition, whereas patients $A$ and $C$ were heterozygous for known single nucleotide polymorphisms (SNP) within the intron 4. In addition, two SNP heterozygoses were observed for patient $C$ in both intron 9 and 13. Sequencing also revealed several nucleotide variations in patient $B$. Two heterozygoses for known polymorphisms were identified along with a novel $\mathrm{C}>\mathrm{A}$ nucleotide change in intron 4 . This patient also presented a low number on the TG repeat in intron 9 and a new IVS11+33A>T transversion. Gene regulation and transcription of $P A X 6$ are complex processes; there are two major protein isoforms, PAX6(-5a) and PAX6(+5a), and nine transcripts described. Furthermore, extra transcription regulatory elements have been postulated within PAX6 introns. Considering that neither population distributions on $P A X 6$ polymorphism nor their linkeages with diseases have been reported, a functional effect due to alterations described here cannot be discarded. (Arq Bras Endocrinol Metab 2008; 52/8:1221-1227)
\end{abstract}

Keywords: Encephalocele; Growth hormone; Morning glory syndrome; PAX6 gene; Short stature

\section{RESUMO}

A Ausência de Mutações no Gene PAX6 em Três Casos de Síndrome de Morning Glory Associada à Deficiência Isolada de Hormônio do Crescimento.

A síndrome de Morning Glory (SMG) é uma displasia óptica congênita associada a anomalias craniofaciais, principalmente encefalocele basal e hipopituitarismo. Os sinais clínicos são variados e muitas vezes ocultos. O gene PAX6 está envolvido na morfogênese ocular e se expressa em vários tecidos oculares durante o desenvolvimento do sistema nervoso central. $O$ objetivo deste estudo foi avaliar o gene PAX6 na SMG associada com deficiência isolada de hormônio de crescimento. Foram relatados três pacientes pré-púberes $(A, B$ e C) com SMG e baixa estatura por deficiência de hormônio de crescimento tratados com hormônio de crescimento recombinante humano. As seqüências codificadoras e não-codificadoras correspondentes ao PAX6 em diferentes clinical case report

\author{
GIL GuerRa-Junior \\ Angela Maria Spinola-Castro \\ AdRIANA A. SIVIERO-MIACHON \\ Roberto Gomes Nogueira \\ Sofia Helena V. Lemos-MarinI \\ LILIA Freire Rodrigues D'SOUZA-LI \\ Priscila Cristina da Silva \\ EMERSON Salvador S. França \\ Fernanda Caroline Soardi \\ Maricilda Palandi de Mello
}

Department of Pediatrics,

Pediatric Endocrinology Unit, Faculty of Medical Sciences, University of Campinas (Unicamp), (GGJ, SHVLM, LFRSL) Campinas, SP, Brazil; Department of Pediatrics, Pediatric Endocrinology Unity, School of Medicine, Federal University of Sao Paulo (Unifesp/EPM) (AMSC, AASM), Sao Paulo, SP, Brazil; Department of Radiology, School of Medicine, Unifesp/EPM (RGN), Sao Paulo, SP, Brazil; Center of Molecular Biology and Genetic Engineering (CBMEG) (PCS, ESSF, FCS, MPM), Unicamp, Campinas, SP, Brazil

Received in 24/8/2008

Accepted in 14/10/2008 
transcritos foram analisadas por seqüenciamento direto. Variações nucleotídeas com trocas pontuais de aminoácidos não foram encontradas. O paciente A apresentou uma transição nova IVS2+9G>A, enquanto os pacientes $A$ e $C$ foram heterozigotos para um polimorfismo (SNP) no íntron 4. Ainda, dois SNPs em heterozigose nos íntrons 9 e 13 foram observados no paciente $C$. O seqüenciamento também mostrou várias variações nucleotídeas no paciente $B$. Dois SNPs conhecidos com a alteração nucleotídea nova $C>A$ no íntron 4 foram observados em heterozigose. Este paciente também apresentou um baixo número de repetições TG no íntron 9 e uma nova transversão IVS11+33A>T. A regulação e a transcrição do gene $P A X 6$ são um processo complexo; existem 2 isoformas principais da proteína, PAX6(-5a) e PAX6(+5a) e 9 transcritos descritos. Considerando que nem a distribuição de SNPs no PAX6 e nem as suas ligações com as doenças foram relatadas, um defeito funcional devido às alterações descritas não pode ser descartado. (Arq Bras Endocrinol Metab 2008; 52/8:1221-1227)

Descritores: Encefalocele; Hormônio do crescimento; Morning glory syndrome; Gene PAX6; Estatura baixa

\section{INTRODUCTION}

M orning glory syndrome (MGS) is a congenital malformation of the optic disc characterized by an enlarged, funnel-shaped optic disc and an elevated pigmented peripapillary tissue annulus, firstly described in 1970 and named by Kindler (1) due to a resemblance to the flower of the same name. MGS can be associated with basal encephalocele and hypopituitarism. Basal (meningo) encephalocele is an sporadic and occult malformation, described in $67,7 \%$ of MGS patients, usually associated with midline defects, such as cleft palate and corpus callosum agenesis, optic disc and other brain anomalies, and hormonal disturbance (2-5).

Azuma and cols. (6) identified PAX6 (paired box 6) gene $(11 \mathrm{pl} 3)$ mutations in pedigrees with optic nerve malformations, including coloboma, morning glory disc anomaly, optic nerve hypoplasia/aplasia and persistent hyperplastic primary vitreous. Some of these mutations may affect transcriptional repression of the $P A X 2$ promoter mediated by $P A X 6$. In view of the detection of $P A X 2$ gene mutations in papillorenal syndrome, it has been suggested that modifications in $P A X 2$ function, as a result of $P A X 6$ mutations, may affect some phenotypic expressions including those of the optic nerve malformations. Furthermore, Marquardt and cols. (7) demonstrated that $P A X 6$ controls the transcriptional activation of retinogenic basic helix-loop-helix factors that predisposes subsets of multipotent retinal progenitor cells (RPCs) towards different retinal cell fates, thereby mediating the full retinogenic potential of RPCs. Nonethe- less, the molecular mechanisms mediating the RPCs retinogenic potential have not been established yet.

Kioussi and cols. (8) showed that PAX6 is also implicated in the development of both, Rathke pouch and early anterior pituitary gland, whereas its expression controls the boundaries of somatotrope, lactotrope, and thyrotrope cell types. In the absence of $P A X 6$ the thyrotrope cells lineage increases markedly along with the decrease of somatotrope and lactotrope cells. $=$

The aim of the present study is to evaluate molecular features in PAX6 gene in three patients with MGS and isolated growth hormone deficiency.

\section{SUBJECTS AND METHODS}

\section{Case reports}

Three patients with MGS, two from Federal University of Sao Paulo (Unifesp/EPM - Brazil) (A and B) and one from University of Campinas (Unicamp - Brazil) (C) were referred to the Pediatric Endocrine Clinic, due to short stature. The ophthalmological exam, including a retinography, showed typical abnormalities of the MGS, comprising an optical disk with an enlarged choanoid and cupped aspect, with a pink pigmentation and a central white mass which hid the way of the vessels at the bottom of the disk. The disk was surrounded by a little elevated grey ring, with irregular borders and mixed with colored areas. The vessels were multiple, thin and radiated (Figure 1). 


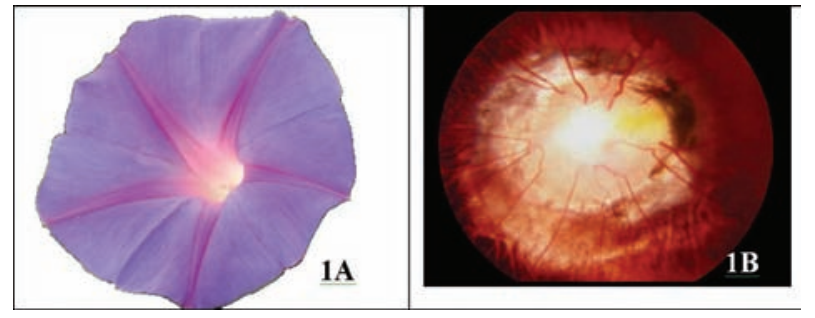

Figure 1. 1A: The morning glory flower; 1B: Left eye retinography from patient $A$ with a morning glory aspect (Figure 1B was gently offered by Prof. Paulo Mitsuru Imamura, from Department of Ophthalmology, Unifesp/EPM).

All patients were normally delivered at full term, after uneventful pregnancies. Patients A and B had unremarkable medical histories, but patient $\mathrm{C}$ presented failure to thrive and delayed psychomotor development, beginning at one year of age. None of them had family history of hormonal disorders or congenital anomalies. Clinical and laboratory data are summarized in Table 1.

Table 1. Clinical and laboratory data from three patients with Morning Glory Syndrome and isolated growth hormone deficiency.

\begin{tabular}{|c|c|c|c|}
\hline & Patient A & Patient B & Patient C \\
\hline Birth weight (kg) & 2.82 & 2.80 & 2.85 \\
\hline Birth length $(\mathrm{cm})$ & 49.0 & 49.0 & 46.0 \\
\hline Strabismus & + & - & + \\
\hline Ocular hypertelorism & - & - & + \\
\hline Microphthalmia & - & + & - \\
\hline Visual acuity & $20 / 400$ & $20 / 400$ & $15 / 400$ \\
\hline \multicolumn{4}{|l|}{ At endocrine evaluation } \\
\hline Age (years-old) & 8.0 & 12.2 & 9.0 \\
\hline Weight in Kg (SDS) & $16.2(-4.1)$ & $27.6(-2.4)$ & $20.0(-2.7)$ \\
\hline Height in cm (SDS) & $100.0(-5.2)$ & $128.5(-3.0)$ & $107.0(-4.6)$ \\
\hline Pubertal stage & Tanner I & Tanner I & Tanner I \\
\hline GH 1 (ng/mL)' & 3.6 & 0.9 & 1.9 \\
\hline $\mathrm{GH} 2(\mathrm{ng} / \mathrm{mL})^{2}$ & 0.2 & 0.5 & 1.6 \\
\hline IGF-1 (ng/mL) ${ }^{3}$ & 67.0 & 115.0 & 43.0 \\
\hline IGFBP-3 (ng/mL) ${ }^{4}$ & 1,530 & 2,650 & 1,421 \\
\hline TSH $(I U / L)^{5}$ & 3.8 & 1.8 & 4.8 \\
\hline Free T4 (ng/dL) ${ }^{6}$ & 1.1 & 1.1 & 1.2 \\
\hline Cortisol $(\mathrm{mcg} / \mathrm{dL})^{7}$ & 13.4 & 20.4 & 17.0 \\
\hline Bone age (Greulich-Pyle) & 5.6 & 11.0 & 7.0 \\
\hline
\end{tabular}

SDS= standard-deviation score; $\mathrm{GH} 1$ = growth hormone after $0.15 \mathrm{mg} / \mathrm{m}^{2}$ of oral clonidine; ' normal range $=\mathrm{NR}=>7.0 \mathrm{ng} / \mathrm{mL} ; \mathrm{GH} 2$ after $0.1 \mathrm{lU} / \mathrm{kg}$ crystalline insulin i.v.; ${ }^{2} \mathrm{NR}=>7.0 \mathrm{ng} / \mathrm{mL} ;{ }^{3} \mathrm{NR}=23.0$ to $392.0 \mathrm{ng} / \mathrm{mL} ;{ }^{4} \mathrm{NR}=1,250$ to $6,350 \mathrm{ng} /$ $\mathrm{mL} ;{ }^{5} \mathrm{NR}=0.4$ to $6.0 \mathrm{IU} / \mathrm{L} ;{ }^{6} 0.8$ to $2.0 \mathrm{ng} / \mathrm{dL} ;{ }^{7} \mathrm{NR}=5.0$ to $25.0 \mathrm{mcg} / \mathrm{dL}$
During follow-up, all patients showed low growth rate (below $3 \mathrm{~cm} /$ year) and a hormonal profile compatible with isolated growth hormone deficiency (Table 1). They had no symptoms of diabetes insipidus. A magnetic resonance imaging (MRI - Phillips Gyroscan 1,5T), with sagittal and coronal images from the sellar region, was obtained on the Tl weighted spin echo (TIWSE) sequence before and after the paramagnetic contrast medium intravenous administered, and in T2 weighted spin echo sequence. It was observed inferior and posterior herniation of the sella content through the sella floor defect towards the sphenoidal sinus (basal encephalocele) in patients A and B. Patient $\mathrm{C}$ did not present encephaloceles, but he had a hypoplastic adenohypophysis, ectopic neurohypophysis with a normal stalk (Figure 2).
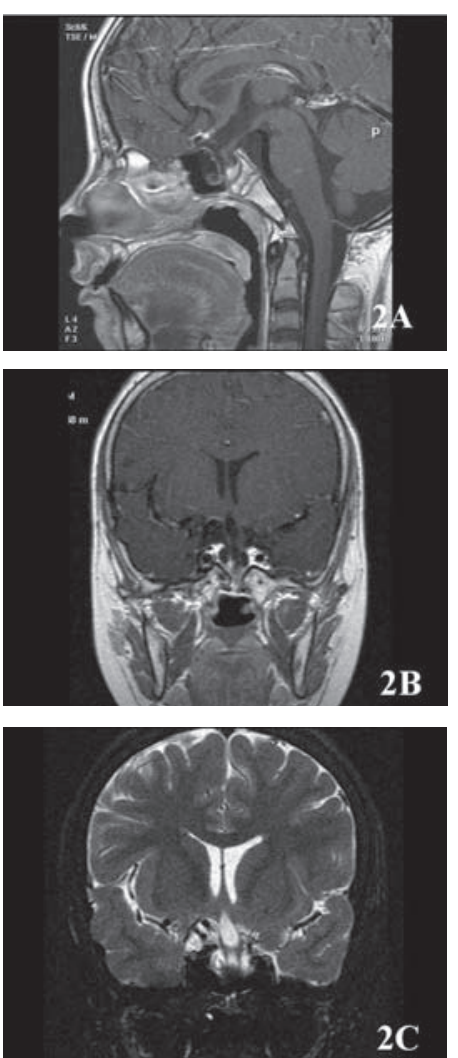

Figure 2. Magnetic resonance imaging (MRI) from patient $A$ : 2A: MRI TSE sequencing, T1-ponderated, sagittal plane, showing inferior and posterior herniation of the sella content through the sella floor defect towards the sphenoidal sinus (basal encephalocele); 2B: MRI TSE sequencing, T1-ponderated, coronal plane, after contrast, showing inferior herniation and deformity of optic chiasm, as well as posterior herniation of sella content towards the sphenoidal sinus; $2 \mathrm{C}$ : MRI, T2-ponderated, coronal plane, showing sella floor defect, inferior herniation of optic chiasm, and posterior herniation of sella content towards the sphenoidal sinus. 
Patient A started growth hormone replacement therapy (rhGH) at age of 10 , at a dose of $0.03 \mathrm{mg} / \mathrm{kg} /$ day, by subcutaneous injections, presenting with a growth rate of $11.5 \mathrm{~cm} /$ year during the first year of treatment and a progressive decrease, onward to $5 \mathrm{~cm}$ and $3 \mathrm{~cm}$, respectively at the $2^{\text {nd }}$ and $3^{\text {rd }}$ year of treatment, regardless of an increase in the rhGH dosage. Patient $\mathrm{B}$ started rhGH at the age of 13 at a dose of 0.03 $\mathrm{mg} / \mathrm{kg} /$ day. During the first two years of therapy the growth rate was respectively $12 \mathrm{~cm} /$ year and $5.0 \mathrm{~cm} /$ year, even though rhGH dosage was increased up to $0.05 \mathrm{mg} / \mathrm{kg} /$ day at the second year. Patient $\mathrm{C}$ was started on rhGH at the age of nine, at a dose of $0.05 \mathrm{mg} /$ $\mathrm{kg} /$ day. During the first two years of treatment, growth rate was respectively $6.5 \mathrm{~cm} /$ year during the first year and subsequently $5 \mathrm{~cm} /$ year. It is worth noting that during the second year the dosage of growth hormone was increased to $0.075 \mathrm{mg} / \mathrm{kg} /$ day. No other hormonal deficiencies were observed. Patient $\mathrm{C}$ showed a progressive ocular dysfunction and became blind at the right eye. The replacement therapy was discontinued after the third year. The presence of anti-GH antibodies was ruled out in the three cases. Currently, patients A and C are almost near final height and end up very short (height scores below -2 SDS). Patient B is still under rhGH therapy despite poor response.

\section{Molecular studies}

Genomic DNA was isolated from blood leukocytes using standard techniques (9). All fourteen coding and non-coding exons of the human PAX6 gene were amplified by PCR using specific primers listed in Table 2. PCR reactions were carried in $50 \mu \mathrm{l}$ containing: $\sim 500 \mathrm{ng}$ genomic DNA, 10\% DMSO, $200 \mu \mathrm{M}$ each dNTP, 20 pmoles of each primer, lxTaq buffer solution (Invitrogen, CA. USA) and 1.5 units of recombinant Taq DNA polymerase (Invitrogen, CA. USA). In general, cycling profiles were: $94{ }^{\circ} \mathrm{C}$ for $5 \mathrm{~min} ; 94^{\circ} \mathrm{C}$ for $1 \mathrm{~min}, \mathrm{Ta}\left({ }^{\circ} \mathrm{C}\right)$ specific for each primer pair (Table 2) for $1 \mathrm{~min}, 72{ }^{\circ} \mathrm{C}$ for $1 \mathrm{~min}$ ( 30 cycles); and a final extension step of $72 \mathrm{C}$ for 5 min. PCR products were purified with Wizard SV Gel and PCR Clean-UP System (Promega, Madison, WI, USA) and directly sequenced in both sense and antisense orientations using amplification primers; for long fragments, additional sequencing with an internal primer was performed (Table 2). Sequencing reactions were conducted using Big Dye ${ }^{\mathrm{TM}}$ Terminator Cycle Sequencing Kit V3.1 Ready Reaction (ABI PRISM / PE Biosystems, Foster City, CA, USA) and DNA sequences were obtained in an ABI PRISM® 3700 DNA Analyzer (ABI PRISM/PE Biosystems, Foster City, CA, USA). The electropherograms were analyzed by Chromas Lite program (free-software). Sequencing data obtained in this study was compared to the PAX6 gene sequence described by International Human Genome Consortium (GENEBANK access \# NC_000011) using the GeneRunner v3.05 (free-software).

Table 2. Primers used for PAX6 PCR amplifications and sequencing.

\begin{tabular}{|c|c|c|}
\hline Region & Primer sequence $\left(5^{\prime}-3^{\prime}\right)^{1}$ & $\mathrm{Ta}^{2}\left({ }^{\circ} \mathrm{C}\right)$ \\
\hline Exon 1 & $\begin{array}{l}\text { s - TCATATTCAAACAAACGGACC } \\
\text { as - AAGAGTGTGGGTGAGGGAAGT }\end{array}$ & 57 \\
\hline Exon 2 & $\begin{array}{l}\text { s - TTATCTCTCACTCTCCAGCCG } \\
\text { as - GGAGACCTGTCTGAATATTGC }\end{array}$ & 55 \\
\hline Exon 3 & $\begin{array}{l}\text { s - TGTGGGTGTAATGCTGGGACT } \\
\text { as - GAATATCCCCAATCTGTTTCCC }\end{array}$ & 61 \\
\hline Exon 4 & $\begin{array}{l}\text { s - TTGGGAGTTCAGGCCTACCT } \\
\text { as - CCAGTATCGAGAAGAGCCAAG }\end{array}$ & 58 \\
\hline $\begin{array}{l}\text { Exon } 5^{3} \\
\text { region } 1\end{array}$ & $\begin{array}{l}\text { s - TCAAACTTGACGTGCAGCTAG } \\
\text { as - ATAGTGTTCCCCATCCCTCCT }\end{array}$ & 58 \\
\hline $\begin{array}{l}\text { Exon } 5 \\
\text { region } 2\end{array}$ & $\begin{array}{l}\text { s - CTAAGGTTGGACCACAGGGAT } \\
\text { as - TCCAGAAATGTTTCCATCACC }\end{array}$ & 59 \\
\hline $\begin{array}{l}\text { Exon } 5 \\
\text { region } 3\end{array}$ & $\begin{array}{l}\text { s - ACATACTGGCTGCTCTGGTTG } \\
\text { as - CTACAGCCATAACCCCAGCAG }\end{array}$ & 59 \\
\hline $\begin{array}{l}\text { Exon } 5 \\
\text { region } 4\end{array}$ & $\begin{array}{l}\text { s - TGGCTGCAGTGTTTATGAAGA } \\
\text { as - CACCACCGAGCTGATTCACTC }\end{array}$ & 58 \\
\hline $\begin{array}{l}\text { Exon } 5 \\
\text { region } 5\end{array}$ & $\begin{array}{l}\text { s - TCTTCTTCСTCTTCACTCTGC } \\
\text { as - TGAAAGAGATAGGGAAGGATG }\end{array}$ & 55 \\
\hline Exons 6-7 & $\begin{array}{l}6 \text { s - ATTTATCTACTTCGTTTTGATGC } \\
7 \text { as - AGAGGGTGGGAGGAGGTAAAG }\end{array}$ & 56 \\
\hline $\begin{array}{l}\text { Exon } 6 \\
\text { seq }^{4}\end{array}$ & s - TGGACAATCAAAACGTAAGCT & - \\
\hline Exon 8 & $\begin{array}{l}\text { s - AGCTGAGATGGGTGACTGTGT } \\
\text { as - AAGGGATGCACATATGGAGAG }\end{array}$ & 58 \\
\hline Exon 9 & $\begin{array}{l}\text { s - GGGAATGTTTTGGTGAGGCT } \\
\text { as - ACCTCCAACCAATTCCCTTTA }\end{array}$ & 60 \\
\hline $\begin{array}{l}\text { Exon } 9 \\
\text { seq }^{4}\end{array}$ & s - ACGGAGAAGATTCAGATGAGG & - \\
\hline Exon 10 & $\begin{array}{l}\text { s - GGAACCAGTTTGATGCACAGT } \\
\text { as - GCAGCAGAGCATTIAGCAGAC }\end{array}$ & 58 \\
\hline $\begin{array}{l}\text { Exons } \\
11-12\end{array}$ & $\begin{array}{l}\text { s - GTCTGCTAAATGCTCTGCTGC } \\
\text { as - AGCTCTCAAGGGTGCAGACAC }\end{array}$ & 60 \\
\hline Exon 13 & $\begin{array}{l}\text { s - TGGCTGTGTGATGTGTTCCTC } \\
\text { as - AGAAAACTTGCAGTCTCAGGC }\end{array}$ & 58 \\
\hline Exon 14 & $\begin{array}{l}\text { s - CCATGTCTGTTTCTCAAAGGGA } \\
\text { as - CCCCAGTGGTACAATACAGGA }\end{array}$ & 59 \\
\hline
\end{tabular}

${ }^{1} \mathrm{~S}=$ sense; as = antisense; ${ }^{2} \mathrm{Ta}=$ annealing temperature used for PCR; ${ }^{3}$ The exon 5 was divided in 5 fragments due its long size; "Primers used for sequencing only. 


\section{RESULTS}

Genomic sequences corresponding to PAX6 different transcripts were analyzed by direct sequencing. PAX6 gene is transcribed into nine different transcripts. They differ to each other by alternative splicings of exons $1-4$ in the 5'-UTR. Whereas sequencing of PAX6 coding DNA did not reveal any putative aminoacid change, new variations and several already known SNPs were found in non-coding regions (Table 3 ).

Patient A was found to be heterozygous for a novel IVS2+9G $>A$ transition in intron 2. Two novel polymorphisms were observed for patient $\mathrm{B}$ : transversions g.14807C $>\mathrm{A}$ and IVS1 $1+33 \mathrm{~A}>\mathrm{T}$ located in intron 4 and 11, respectively. Conversely, patient $\mathrm{C}$ did not present any novel nucleotide variation.

Patients $\mathrm{A}$ and $\mathrm{C}$ showed heterozygosis for the g.14592C >A (SNP-rs694617) transversion and also for the indel g.15449_15450insG (SNP-rs5790867) both located in intron 4 . In addition, patient $\mathrm{C}$ presented the g.24214A $>$ T (SNP-rs2239789) and IVS13+43T>G (SNP-rs3026393) transversions in intron 9 and 13, respectively.

Several SNPs were also observed for patient B. The heterozygosis for the nucleotide changes g.14806T>G (SNP-rs3026368) and g.15003A>G (SNP-rs3026369) within intron 4 were found, additionally only this patient was homozygous for $+\mathrm{G}$ allele at the indel g.15449_15450insG (SNP-rs5790867).

An intron 9 microsatellite formed by TG Short Tandem Repeat (STR) was also investigated. Normally,
PAX6 alleles bear a sequence of $(\mathrm{TG})_{19-29}$ repeats interrupted by a $\mathrm{GG}$ dinucleotide and followed by a $(\mathrm{TG})_{7}$ repeat. Patients A and C were heterozygous for $(\mathrm{TG})_{19 / 21}$ - GG - $(\mathrm{TG})_{7}$ sequences, however patient B was heterozygous for $(\mathrm{TG})_{16 / 19}$ repeats with absence of the intercalated GG dinucleotide and the last $(\mathrm{TG})_{7}$ repeats (Table 3).

\section{DISCUSSION}

We reported three patients with ocular lesion compatible with MGS associated with isolated growth hormone deficiency with a limited response to $\mathrm{rhGH}$ replacement and PAX6 gene molecular features.

Neither hereditary nor pregnancy possible events according to published data so far (10) had influenced MGS in the cases described here. Reports on sex ratio have been controversial, but some authors consider MGS to be more commom in females $(10,11)$. Nevertheless all patients studied in the present paper were males.

Likewise, the three described patients had bilateral disease whereas MGS is frequently unilateral and nonprogressive. In addition, all patients became blind during the follow-up, which is a rare event (10-13). It was impossible to determine if rhGH have had any influence on the worsening the eye disease, since there are no reports available on this subject.

The patients in this report had mild midline defects such as hypertelorism (patient C), strabismus (patients A and $\mathrm{C}$ ), and microphthalmia (patient B), however no signs of systemic diseases or any hormonal defect other

Table 3. PAX6 sequence variation dada in three patients with morning glory syndrome and isolated growth hormone deficiency.

\begin{tabular}{|c|c|c|c|c|c|c|c|c|}
\hline & $\begin{array}{c}\text { intron } 2 \\
(\text { IVS }+9 G>A)\end{array}$ & & Intron 4 & & $\begin{array}{c}\text { Intron } 9 \\
\text { (STR-(TG)n) }\end{array}$ & Intron 9 & $\begin{array}{c}\text { Intron } 11 \\
\text { (IVS11+33T>A) }\end{array}$ & Intron 13 \\
\hline Patient A & $G / A$ & C/A & $\mathrm{T} / \mathrm{T}|\mathrm{C} / \mathrm{C}| \mathrm{A} / \mathrm{A}$ & $-G /+G$ & $(\mathrm{TG})_{19 / 21}-\mathrm{GG}-(\mathrm{TG})_{7}$ & $A / A$ & $T / T$ & $T / T$ \\
\hline Patient B & $G / G$ & $\mathrm{C} / \mathrm{C}$ & $T / G|C / A| A / G$ & $+G /+G$ & $(\mathrm{TG})_{16 / 19}$ & $A / A$ & $\mathrm{~T} / \mathrm{A}$ & $T / T$ \\
\hline Patient C & $G / G$ & $\mathrm{C} / \mathrm{A}$ & $\mathrm{T} / \mathrm{T}|\mathrm{C} / \mathrm{C}| \mathrm{A} / \mathrm{A}$ & $-G /+G$ & $(\mathrm{~T} G)_{19 / 21}-\mathrm{GG}-(\mathrm{T} \mathrm{G})_{7}$ & $A / T$ & $T / T$ & $T / G$ \\
\hline $\begin{array}{l}\text { Genomic } \\
\text { position' }\end{array}$ & g. $7743 G>A$ & g. $14592 \mathrm{C}>\mathrm{A}$ & $\begin{array}{c}\text { g. } 14806 \mathrm{~T}>\mathrm{G} \mid \text { g. } 14807 \mathrm{C}>\mathrm{A} \mid \\
\mid \text { g. } 15003 \mathrm{~A}>\mathrm{G}\end{array}$ & g. 15449->G & g. $24083-g .24156$ & g.24214A>T & g. $24943 T>A$ & g.27895T>G \\
\hline SNP2 ${ }^{2}$ & not described & rs694617 & $\begin{array}{c}\text { rs3026368 | } \\
\text { not described | rs3026369 }\end{array}$ & rs5790867 & rs $10525266^{4}$ & rs2239789 & not described & rs3026393 \\
\hline Frequency ${ }^{3}$ & - & $100 \% \mathrm{C}$ & $-1-1-$ & - & - & $50 \% \mathrm{~A} \mid 50 \% \mathrm{~T}$ & - & - \\
\hline
\end{tabular}

'Based in Ensembl - ENSG00000007372 (http://www.ensembl.org/Homo sapiens); 2SNP number at NCBI SNP database (http://www.ncbi.nlm.nih.gov/SNP); 3 SNP Frequency for several populacional groups; NCBI SNP database dada (http://www.ncbi.nlm.nih.gov/SNP); ${ }^{4}$ SNP describe as an in del (TG) ${ }_{1-10} /-;$ therefore, normal alleles are (TG) ${ }_{19 / 29}$ - CG - (TG) 
than growth hormone deficiency was remarked. Most cases of MGS are considered as isolated ocular abnormalities, but other malformations of the skull, facial, mainly midline defects, and central nervous system may occur (13). Associations with genetic syndromes and systemic diseases, including growth hormone deficiency have also been reported $(10,11)$.

The hormonal deficiency described in the other reported cases is usually secondary to the compression of the pituitary gland by basal encephaloceles $(14,15)$, but the natural course of the hypothalamic-pituitary dysfunction is at present still unclear. In our patients the causative factors were not clearly identified. There is always a possibility that the growth hormone deficiency could have occurred by chance. Nonetheless, the growth hormone deficiency was not an isolated fact, and the patients did not have a good response to rhGH treatment, according to Ranke predictive models (16). There are no reports about other patients with MGS that had been treated with rhGH. Our patients had an acceptable response at the beginning of the treatment but a normal growth rate could not be maintained, even with a higher dose than usual, during the subsequent years. GH, IGF$\mathrm{I}$ and IGFBP-3 profile did not point out a possible GH resistance.

Regarding pituitary function, there was no progression of the hormonal deficiencies, even in what concerns diabetes insipidus, considered a common event associated with MGS $(10,13)$.

In order to verify if mutations on PAX6 gene could explain MGS phenotypes in those patients, we proceed with PAX6 sequence analysis. However, nucleotide alterations were not identified in the protein coding sequence. PAX6 gene sequence analysis revealed several SNPs and at last one non-described heterozygous nucleotide was found in patients A and B. PAX6 protein is a transcription factor with important functions in the development of eyes and central nervous tissues (17). The most abundant transcripts present 13 or 14 exons depending on the inclusion or not of exon $5 \mathrm{a}$. Therefore, there are two major PAX6 isoforms: PAX6(-5a), with 422 amino acids, and PAX6 $(+5 a)$, with 436 amino acids resulting from the insertion of a 14 amino acid-long sequence in the paired domain (18). Furthermore, alternative splicings are responsible for the production of nine different transcripts, which results from distinct exon combinations in 5'UTR and are transcribed in different tissues, although most of them are mainly found in the cerebral tissue. Evidences suggest that the complexity of $P A X 6$ transcription, regulation and expression is probably important for its multiple functions, whereas the spatiotemporal regulation and the expression of PAX6 isoforms are still not well understood. Recently, some elements corresponding to transcription regulatory consensus sequences have been described within PAX6 introns, suggesting that intronic sequences are important for the regulation maintenance in a high conserved gene (19). Concerning to SNPs already described, there is only one paper that failed to demostrate the linkage of SNP rs2239789 to myopia (20). In addition to the SNPs identified in the present study and those already described, PAX6 gene has a TG microsatellite within intron 9. Dinucleotide repeats located in introns are not generally considered to have functional roles in gene expression. However, their highly variable nature suggests a role as modifiers of RNA splicing. To support this idea, there is the finding that a variable number of TG repeats present in intron 8 of CFTR gene contributes to phenotype diversity in Cystic Fibrosis by forming RNA secondary structures that alter exon 9 splicing process (21). Linkages of TG repeats within intronic regions of different genes, including $P A X 7$ which belongs to the same PAX6 gene family, have been described in a few diseases (22-24). Therefore, it is possible that nucleotide alterations within introns might have effects in transcript productions. Taking this hypothesis, PAX6 gene alterations found in patients $\mathrm{A}, \mathrm{B}$ and $\mathrm{C}$, whereas they cannot be considered as mutations, they could be probably associated with the phenotype. Considering that population studies on the distribution of PAX6 gene SNPs are not yet available in the database, a well conducted evaluation on normal individuals using novel and described SNPs must be performed to test this hypothesis. In summary, a functional effect of novel and known alterations described here for MGS patients cannot promptly be rejected.

Although MGS is usually a non-progressive untreatable disease, accurate diagnosis is important due to its association with systemic anomalies and increased incidence of retinal detachment (13). Undoubtedly, the disease manifests with a broad spectrum of characteristics, and we might have faced a new expression of the disorder. Notwithstanding, dysplasic optic disc should always be an alert for physicians to the occurrence of an encephalocele (25). Emphasis on these systemic and ocular associations may prompt early detection, and result in benefit from treatment, as well as could possibly be a clue for a better understanding of the disease under the molecular genetics aspects in order to develop a model for further studies. 
No potential conflict of interest relevant to this article was reported.

\section{REFERENCES}

1. Kindler P. Morning glory syndrome: unusual congenital optic disc anomaly. Am J Ophthalmol. 1970;69:376-84.

2. McLaurin RL. Encephalocele and related anomalies. In: Hoffman HJ, editor. Disorder of the developing nervous system: diagnosis and treatment. St. Louis: Blackwell Scientific; 1986.p.153-71.

3. Cohen MM. Selected clinical research involving the central nervous system. J Craniofac Genet Dev Biol. 1990;10:215-38.

4. Formica F, lannelli A, Paludetti G, Di Rocco C. Trans-sphenoidal meningoencephalocele. Child Nerv Syst. 2002;18:195-8.

5. Minotto I, Abdala N, Miachon AA, Spinola e Castro AM, Imamura P, Nogueira RG. Basal encephalocele associated with morning glory syndrome: case report. Arq Neuropsiquiatr. 2007; 65:988-91.

6. Azuma N, Yamaguchi Y, Handa H, Tadokoro K, Asaka A, Kawase E, Yamada M. Mutations of the PAX6 gene detected in patients with a variety of optic-nerve malformations. Am J Hum Genet. 2003;72:1565-70.

7. Marquardt T, Ashery-Padan R, Andrejewski N, Scardigli R, Guillemot $F$, Gruss P. Pax6 is required for the multipotent state of retinal progenitor cells. Cell. 2001;105: 43-55.

8. Kioussi C, O'Connell S, St-Onge L, Treier M, Gleiberman AS, Gruss P, Rosenfeld MG. Pax6 is essential for establishing ventral-dorsal cell boundaries in pituitary gland development. Proc Nat Acad Sci USA. 1999;96:14378-82.

9. Sambrook J, Fritsch EF, Maniatis TE. Molecular cloning, a laboratory manual. 1989 New York: Cold Spring Harbor.

10. Chan RT, Chan HH, Collin HB. Morning Glory Syndrome. Clin Exp Optom. 2002;85:383-8.

11. Morioka M, Marubayashi T, Masumitsu T, Miura M, Ushio $Y$. Basal encephalocele with morning glory syndrome, and progressive hormonal and visual disturbances: case report and review of the literature. Brain Dev. 1995;17:196-201.

12. Lit ES, D'Amico DJ. Retinal manifestations of morning glory disc syndrome. Int Ophthalmol Clin. 2001;41:131-8.

13. Lee BJ, Traboulsi El. Update on the morning glory disc anomaly. Ophthalmic Genet. 2008;29:47-52.

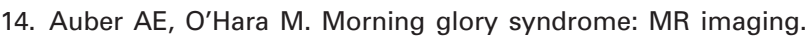
Clin Imaging. 1999; 23:152-8.

15. Koral K, Geffner ME, Curran JG. Trans-sphenoidal and sphenoethmoidal encephalocele: report of two cases and review of the literature. Australas Radiol. 2000;44:220-4.
16. Ranke MB, Lindberg A, Chatelain P, Wilton P, Cutfield W, Albertsson-Wikland K, Price DA. Derivation and validation of a mathematical model for predicting the response to exogenous recombinant human growth hormone $(\mathrm{GH})$ in prepubertal children with idiopathic GH deficiency. KIGS International Board. Kabi Pharmacia International Growth Study. J Clin Endocrinol Metab. 1999;84:1174-83.

17. Callaerts P, Halder G, Gehring WJ. PAX-6 in development and evolution. Annu Rev Neurosci. 1997;20:483-532.

18. Epstein JA, Glaser T, Cai J, Jepeal L, Walton DS, Maas RL. Two independent and interactive DNA-binding subdomains of the Pax6 paired domain are regulated by alternative splicing. Genes Dev. 1994;8(17):2022-34.

19. Kleinjan DA, Seawright A, Childs AJ, van Heyningen V. Conserved elements in Pax6 intron 7 involved in (auto)regulation and alternative transcription. Dev Biol. 2004;265(2):462-77.

20. Mutti DO, Cooper ME, O'Brien S, Jones LA, Marazita ML, Murray JC, Zadnik K. Candidate gene and locus analysis of myopia. Mol Vis. 2007;13:1012-9.

21. Hefferon TW, Groman JD, Yurk CE, Cutting GR., A variable dinucleotide repeat in the CFTR gene contributes to phenotype diversity by forming RNA secondary structures that alter splicing. Proc Natl Acad Sci USA. 2004; 101 (10): 3504-9.

22. Sjakste $T$, Kalis $M$, Poudziunas I, Pirags $V$, Lazdins $M$, Groop L, Sjakste N. Association of microsatellite polymorphisms of the human 14q13.2 region with type 2 diabetes mellitus in Latvian and Finnish populations. Ann Hum Genet. 2007; 71(6):772-6.

23. Sjakste T, Eglite J, Sochnevs A, Marga M, Pirags V, Collan $Y$, Sjakste N. Microsatellite genotyping of chromosome 14q13.2$14 q 13$ in the vicinity of proteasomal gene PSMA6 and association with Graves' disease in the Latvian population. Immunogenetics. 2004;56(4):238-43.

24. Ziman MR, Pelham JT, Mastaglia FL, Kay PH. Characterization of the alternate allelic forms of human PAX7. Mamm Genome. 2000;11(4):332-7.

25. Hodgkins , Lees M, Lawson J, Reardon W, Leitch J, Thorogood $\mathrm{P}$, et al. Optic disc anomalies and frontonasal dysplasia. Br J Ophthalmol. 1998;82:290-3.

\section{Correspondence to:}

Gil Guerra-Junior

Faculty of Medical Sciences PO Box 6111 , Unicamp

13083-970 Campinas, SP, Brazil

E-mail: gilguer@fcm.unicamp.br 